\title{
Incidence and mortality of ischemic stroke subtypes in Joinville, Brazil: a population-based study
}

\author{
Incidência e mortalidade dos subtipos de AVCi em Joinville, Brasil: um estudo de base \\ populacional
}

\author{
Marcos C. Lange', Norberto L. Cabral², Carla H. C. Moro², Alexandre L. Longo², Anderson R. Gonçalves², \\ Viviane F. Zétola ${ }^{1}$, Tatjana Rundek ${ }^{3}$
}

\begin{abstract}
Aims: To measure the incidence and mortality rates of ischemic stroke (IS) subtypes in Joinville, Brazil. Methods: All first-ever IS patients that occurred in Joinville from January 2005 to December 2006 were identified. The IS subtypes were classified by the TOAST criteria, and the patients were followed-up for one year after IS onset. Results: The age-adjusted incidence per 100,000 inhabitants was 26 (17-39) for large-artery atherosclerosis (LAA), 17 (11-27) for cardioembolic (CE), 29 (20-41) for small vessel occlusion (SVO), 2 (0.6-7) for stroke of other determined etiology (OTH) and 30 (20-43) for stroke of undetermined etiology (UND). The 1-year mortality rate per 100,000 inhabitants was 5 (2-11) for LAA, 6 (3-13) for CE, 1 (0.1-6) for SVO, 0.2 (0-0.9) for OTH and 9 (4-17) for UND. Conclusion: In the population of Joinville, the incidences of IS subtypes were similar to those found in other populations. These findings highlight the importance of better detection and control of atherosclerotic risk factors.
\end{abstract}

Keywords: stroke, risk factors, Latin America, epidemiology.

\section{RESUMO}

Objetivos: Avaliar as incidências e as taxas de mortalidade dos subtipos de acidente vascular cerebral (AVC) isquêmico em Joinville, Brasil. Métodos: A partir do Registro de AVC de Joinville, um banco de dados de base populacional em curso, foram identificados todos os primeiros eventos de AVC isquêmico que ocorreram em Joinville entre janeiro de 2005 e dezembro de 2006. Os subtipos foram classificados pelos critérios de TOAST, e os pacientes foram seguidos por um ano após o evento. Resultados: A incidência ajustada por idade por 100.000 habitantes foi de 26 (17-39) para a aterosclerose da artéria grande (AGA), 17 (11-27) para cardioembolia (CE), 29 (20-41) para a oclusão de pequena artéria (OPA), 2 (0,6-7) para outras etiologias determinadas (OTR) e 30 (20-43) para etiologia indeterminada (IND). A taxa de mortalidade de 1 ano por 100.000 habitantes foi de 5 (2-11) para AGA, 6 (3-13) para CE, 1 (0,1-6) para OPA, 0,2 (0-0,9) para OTR e 9 (4-17) para IND. Conclusão: Na população de Joinville, as incidências dos subtipos foram semelhantes aos encontrados em outras populações. Estes resultados destacam a importância de uma melhor detecção e controle dos fatores de risco para aterosclerose.

Palavras-chave: acidente vascular cerebral, fatores de risco, América Latina, epidemiologia.

Previous population-based studies reported the incidence and mortality of ischemic stroke (IS) subtypes in different settings, most of them on the White population from high-income countries ${ }^{1,2,3,4,5,5,7,8}$. In Latin America, there is only one study, which was conducted in a Spanish and Mestizo population in Iquique, Chile9. As far as we know, no previous study has reported IS subtypes rates among predominantly White people from Latin America.
The crude annual incidence rate of IS in Brazil range from 62 to 92 per 100,000 inhabitants with a mixed pattern of cardiovascular risk, characterized by high prevalence of ischemic heart disease, dyslipidemia, hypertension and diabetes ${ }^{10,11}$. Determining the incidence, mortality and risk factors among IS subtypes may help to improve the public health actions and reduce the IS disease burden ${ }^{12,13}$.

\footnotetext{
'Universidade Federal do Paraná, Hospital de Clínicas, Divisão de Neurologia, Curitiba PR, Brazil;

${ }^{2}$ Universidade da Região de Joinville, Hospital Municipal São José, Joinville SC, Brazil;

${ }^{3}$ University of Miami, Miller School of Medicine, Miami, USA.

Correspondence: Marcos C. Lange; Rua General Carneiros, 181/4 andar; 80060-900 Curitiba PR, Brasil; E-mail marcos.lange@hc.ufpr.br Conflicts of interest: There is no conflict of interest to declare.

Support: Fundação de Amparo a Pesquisa do Estado de Santa Catarina, University of the Region of Joinville and the Joinville Municipal Health Department. Received 10 December 2014; Received in final form 12 March 2015; Accepted 02 April 2015.
} 
Our aim was to determine the incidence, mortality and the risk factors for IS subtypes in Joinville, Brazil.

\section{METHOD}

\section{Study population}

The data were extracted from the Joinville Stroke Registry, an ongoing prospective population-based data bank started in 2005 in Joinville, southern Brazil. The city population was 487047 inhabitants in 2005 and 496050 in 2006 ${ }^{14}$. The city has four general hospitals and one public institutional care facility, for a total of 840 beds, all four hospitals have computed tomography (CT) services available on a 24-h basis. The predominantly race-ethnicity based on skin color from the Joinville is White $(85.6 \%)^{15}$.

We identified all cases of first-ever IS (FEIS) occurring between January 1, 2005 and December 31, 2006. The detailed methods of cohort recruitment have been reported previously ${ }^{10}$.

\section{Diagnosis work-up and criteria}

Ischemic stroke was defined as the presence of signs of sudden focal or global cerebral dysfunction that lasted longer than $24 \mathrm{~h}$ without any apparent nonvascular cause, with brain CT revealing hypodense brain areas with a topography consistent with the clinical syndrome ${ }^{16,17}$.

All patients underwent biochemical, electrocardiographic and radiological tests. For the diagnosis of IS subtypes, all patients underwent extracranial and intracranial Doppler ultrasound, transthoracic echocardiography and at least one brain CT. Whenever possible, imaging of the brain or vessels by magnetic resonance imaging, transesophageal echocardiography or digital angiography was performed. The routine for stroke investigation followed the guidelines issued by the Brazilian Society of Cerebrovascular Diseases ${ }^{17}$. All patients were clinically classified by the Bamford classification and pathophysiologically classified by the TOAST classification in large-artery atherosclerosis (LAA), cardioembolic (CE), small vessel occlusion (SVO), stroke of other determined etiology (OTH) and stroke of undetermined etiology (UND) $)^{18,19}$.

The following cardiovascular risk factors were analyzed: hypertension, diabetes, coronary artery disease, congestive heart failure, previous antiplatelet and anticoagulant treatment, hypercholesterolemia and current smoking. After discharge, a trained nurse contacted all patients by telephone at 30 days and 12 months after IS onset. This routine investigation was performed after obtaining written informed consent. This study was approved by the ethics committee of the hospitals and universities involved.

\section{Statistical analysis}

The data are summarized by their mean and standard deviation for continuous variables and percentage for categorical variables. The non-parametric Kruskal-Wallis test was used to compare the different IS subtypes with respect to categorical variables. The Chi-square test was used to compare the IS subtypes with respect to the homogeneity of the distribution of the qualitative variables and to evaluate the independence between the qualitative variables. The Jarque-Bera test was used to determine how well the continuous variable fit a normal distribution. Student's t test for independent samples (normal distribution) and the Mann-Whitney test were used to examine the differences between IS subtypes with respect to quantitative variables. The annual incidence and the mortality rate per 100,000 inhabitants of the different IS subtypes were analyzed. A 95\% confidence interval (CI) was calculated assuming a Poisson distribution for the number of events. The incidence and mortality rates were calculated using intercensus data from the 2005-2006 periods as the denominators ${ }^{14}$. The crude incidence rates and crude mortality rates were calculated for the years 2005 and 2006, using the sum of the intercensus population from those years as the denominator and the sum of the cases (deaths) from the same years as the numerator. The incidence and mortality rates were age adjusted by the direct method, using the population of Brazil as the standard according to the intercensus projection for the years $2005-2006^{20}$ and Segi's World ${ }^{21}$ population. The results were expressed as multivariable-adjusted odds ratios (ORs) and 95\% confidence intervals (CIs), [OR(95\%CI)]. The age-specific and sex-specific analyses for IS subtypes were also included.

All tests were two tailed. All data analyses were performed using Microsoft Excel 2010 (Microsoft Corporation, USA).

\section{RESULTS}

\section{Incidence}

Over 2 years, we registered 610 patients who had IS. Among them, two who had no brain images were excluded. The final sample was 608 patients. The adjusted 2-year cummulative incidence per 100,000 inhabitants for all IS subtypes was 86 (95\%CI, 79-93). For all IS subtypes, patients were predominantly White, with percentages ranging from $84 \%$ for the OTH subtype to $98 \%$ for CE.

Table 1 shows the crude total, age-adjusted and sex-specific incidences. The highest adjusted incidence rates were registered for UND [30(20-43)] and SVO [29(20-41)]. Among the subtypes, OTH had the lowest incidence [2(0.6-7)]. It was observed an increase of incidence rates with age to all IS subtypes and the age-adjusted incidences for the SVO, UND and LAA subtypes were not significantly higher in men for all age groups.

\section{Stroke risk factors}

Table 2 shows baseline characteristics and risk factors. In the final sample, 427 (70\%) had a previous diagnosis of hypertension, and 287 of those $(67 \%)$ were in regular 
Table 1. Incidence rates by age and sex (per 100,000 per year) of ischemic stroke subtypes in Joinville, Brazil, $2005-2006$.

\begin{tabular}{|c|c|c|c|c|c|c|c|c|c|c|}
\hline \multirow{2}{*}{$\begin{array}{c}\text { Age } \\
\text { (years) }\end{array}$} & \multicolumn{2}{|r|}{ LAA } & \multicolumn{2}{|r|}{ CE } & \multicolumn{2}{|r|}{ SVO } & \multicolumn{2}{|r|}{ Other } & \multicolumn{2}{|c|}{ Undetermined } \\
\hline & $\mathrm{n}$ & Rate $(95 \% \mathrm{Cl})$ & $\mathrm{n}$ & Rate(95\% Cl) & $\mathrm{n}$ & Rate(95\%Cl) & $\mathrm{n}$ & Rate(95\% Cl) & $\mathrm{n}$ & Rate $(95 \% \mathrm{Cl})$ \\
\hline \multicolumn{11}{|l|}{ Men } \\
\hline 0-14 & & & & & & & & & 1 & $0.7(0-4)$ \\
\hline \multicolumn{11}{|l|}{$15-24$} \\
\hline $25-34$ & & & & & & & 1 & $1(0-6)$ & 1 & $1(0-6)$ \\
\hline $35-44$ & 2 & $3(0.3-9)$ & & & 5 & $7(2-15)$ & 3 & $4(0.8-12)$ & 11 & $14(7-26)$ \\
\hline $45-54$ & 21 & 43(26-65) & 8 & $16(7-32)$ & 17 & $35(20-55)$ & 2 & $4(0.5-15)$ & 11 & 22(11-40) \\
\hline $55-64$ & 29 & $121(81-174)$ & 4 & $17(5-43)$ & 31 & 130(88-184) & 3 & $12(3-37)$ & 31 & 130(88-184) \\
\hline $65-74$ & 20 & 165(101-255) & 9 & $74(34-141)$ & 21 & $173(107-265)$ & & & 22 & $181(114-275)$ \\
\hline $75-79$ & 10 & $333(160-612)$ & 7 & 233(94-480) & 3 & 100(21-292) & & & 11 & $366(183-655)$ \\
\hline$\geq 80$ & 10 & $437(209-803)$ & 9 & $393(180-746)$ & 12 & $524(271-915)$ & & & 6 & $262(96-570)$ \\
\hline All Ages & 92 & 19(15-23) & 37 & 8(5-10) & 89 & 18(15-22) & 9 & $2(0.8-3)$ & 94 & 19(15-23) \\
\hline World* & & $36(21-58)$ & & $17(7-34)$ & & $34(20-56)$ & & $2(0.4-11)$ & & $35(20-57)$ \\
\hline Brazil† & & $26(15-42)$ & & $12(5-24)$ & & $25(14-41)$ & & 2(0.3-9) & & $25(14-42)$ \\
\hline \multicolumn{11}{|l|}{ Women } \\
\hline \multicolumn{11}{|l|}{ 0-14 } \\
\hline \multicolumn{11}{|l|}{$15-24$} \\
\hline $25-34$ & & & & & & & 2 & $2(0.3-8)$ & 3 & $3(0.7-10)$ \\
\hline $35-44$ & 2 & $3(0.3-9)$ & 1 & $1(0-7)$ & 3 & $4(0.8-11)$ & 1 & $1(0-7)$ & 2 & $3(0.3-9)$ \\
\hline $45-54$ & 9 & 18(8-34) & 4 & $8(2-20)$ & 12 & $24(12-42)$ & 4 & $8(2-20)$ & 11 & 22(11-39) \\
\hline $55-64$ & 10 & 39(19-71) & 8 & $31(13-61)$ & 20 & $78(47-120)$ & 1 & $4(0.1-22)$ & 6 & 23(9-51) \\
\hline $65-74$ & 20 & $124(76-192)$ & 12 & $75(38-130)$ & 24 & 149(96-222) & 1 & $6(0.2-35)$ & 22 & $137(86-207)$ \\
\hline $75-79$ & 9 & 199(91-378) & 7 & 155(62-319) & 11 & $243(121-435)$ & & & 10 & $221(106-407)$ \\
\hline$\geq 80$ & 11 & $242(121-434)$ & 23 & $507(321-761)$ & 12 & $265(137-462)$ & 1 & $22(0.6-123)$ & 25 & $551(357-814)$ \\
\hline All Ages & 61 & 12(9-16) & 55 & 11(8-14) & 82 & 17(13-21) & 10 & $2(1-4)$ & 79 & 16(13-20) \\
\hline World* & & 19(10-33) & & $18(9-32)$ & & $25(14-41)$ & & $2(0.3-10)$ & & $24(14-37)$ \\
\hline Brazilt & & $14(7-24)$ & & $13(7-23)$ & & 18(10-30) & & $2(0.3-8)$ & & $18(10-27)$ \\
\hline \multicolumn{11}{|l|}{ All } \\
\hline 0-14 & & & & & & & & & 1 & $0.4(0-2)$ \\
\hline \multicolumn{11}{|l|}{$15-24$} \\
\hline $25-34$ & & & & & & & 3 & $2(0.4-5)$ & 4 & $2(0.6-6)$ \\
\hline $35-44$ & 4 & $3(0.7-7)$ & 1 & $0.7(0-4)$ & 8 & 5(2-10) & 4 & $3(0.7-7)$ & 13 & $8(4-14)$ \\
\hline $45-54$ & 30 & $30(20-43)$ & 12 & $12(6-21)$ & 29 & $29(20-42)$ & 6 & $6(2-13)$ & 22 & $22(14-34)$ \\
\hline $55-64$ & 39 & 79(56-107) & 12 & $24(12-42)$ & 51 & 103(76-135) & 4 & $8(2-21)$ & 37 & 75(52-103) \\
\hline $65-74$ & 40 & 142(101-193) & 21 & 74(46-114) & 45 & 159(116-213) & 1 & $3(0.1-20)$ & 44 & 156(113-210) \\
\hline $75-79$ & 19 & $252(152-394)$ & 14 & $186(102-312)$ & 14 & $186(102-312)$ & & & 21 & $279(173-427)$ \\
\hline$\geq 80$ & 21 & $308(190-470)$ & 32 & 469(321-662) & 24 & $352(225-523)$ & 1 & $15(0.4-82)$ & 31 & 454(309-645) \\
\hline All Ages & 153 & 16(13-18) & 92 & $9(7-11)$ & 171 & 17(15-20) & 19 & 2(1-3) & 173 & 18(15-20) \\
\hline World* & & $26(17-38)$ & & $17(11-27)$ & & $29(20-41)$ & & $2(0.6-7)$ & & $30(20-43)$ \\
\hline Brazil† & & $19(13-27)$ & & $12(8-19)$ & & $21(14-30)$ & & $2(0.5-6)$ & & $22(14-32)$ \\
\hline
\end{tabular}

LLA: large-artery atherosclerosis; CE: cardioembolic; SVO: small vessel occlusion; Cl: confidence interval. *Age adjusted to the world WHO population (2000) †Brazil population 2005-2006.

treatment before the ictus. Only 107 (25\%) of all the hypertensive patients had controlled blood pressure, 90 (21\%) of the patients did not have control, and in 90 (21\%) the control state was unknown. As expected, compared to all other IS subtype groups, the OTH subtype group contained fewer patients who had hypertension $(36.8 \%$; $\mathrm{p}=0.004)$. Diabetes was previously recognized in 30\% (184); 52\% (96) were using an oral antidiabetic drug, and $21 \%$ (39) were using insulin therapy. Dyslipidemia was previously recognized in 25\% (149); $56 \%$ (83) of these patients were regularly using medication. Current smokers were most prevalent in the LAA subtype group ( $p=0.036)$. Previous CHF ( $p=0.041), A F(p<0.001)$, the use of antiplatelet medication $(p=0.001)$ and age $(p<0.001)$ were most prevalent among CE IS.

\section{Mortality}

After one year, the overall age-adjusted mortality rate to IS in the present study was 5 (4-6). Table 3 shows the one-year mortality rate. The highest adjusted mortality rates were registered for UND [9 (4-17)] and CE [6 (3-13)], followed by LAA [5(2-11)]. The OTH subtype [0.2 (0-0.9)] had a lower mortality rate than the UND, CE and LAA subtypes. In men and women separately, the OTH subtype had a lower mortality rate than all other IS subtypes to both sexes. 
Table 2. Demographic and risk factors present in the IS subtype groups in Joinville, 2005-2006.

\begin{tabular}{|c|c|c|c|c|c|c|}
\hline & LAA & CE & SVO & Other & Undetermined & nyalue \\
\hline & $n=153$ & $\mathrm{n}=92$ & $\mathrm{n}=171$ & $\mathrm{n}=19$ & $n=173$ & prature \\
\hline White skin color & $144(94.1 \%)$ & $90(97.8 \%)$ & $161(94.2 \%)$ & $16(84.2 \%)$ & $166(96.0 \%)$ & \\
\hline Age, y (mean \pm sd) & $65.9 \pm 12.3$ & $72.3 \pm 12.9$ & $65.1 \pm 11.9$ & $49.2 \pm 13.1$ & $65.5 \pm 15.1$ & $<0.001$ \\
\hline Female sex & $61(39.9 \%)$ & $55(59.8 \%)$ & $82(48.0 \%)$ & $10(52.6 \%)$ & $79(45.7 \%)$ & 0.048 \\
\hline $\mathrm{BMI}>30 *$ & $34(22.5 \%)$ & $13(14.3 \%)$ & $28(16.4 \%)$ & $0(0.0 \%)$ & $25(15.0 \%)$ & 0.083 \\
\hline Hypertension & $105(68.6 \%)$ & $73(79.3 \%)$ & $123(72.0 \%)$ & $7(36.8 \%)$ & $119(68.8 \%)$ & 0.004 \\
\hline Diabetes & $55(35.9 \%)$ & $24(26.1 \%)$ & $51(29.8)$ & $3(15.8 \%)$ & $51(29.5 \%)$ & 0.282 \\
\hline Hypercholesterolemia & 49(32.0\%) & $21(22.8 \%)$ & $33(19.3 \%)$ & $4(21.1 \%)$ & $42(24.3 \%)$ & 0.114 \\
\hline Current smoker & $50(32.7 \%)$ & $16(17.4 \%)$ & $34(19.9 \%)$ & $4(21.1 \%)$ & $40(23.1 \%)$ & 0.036 \\
\hline Previous TIA & $41(26.8 \%)$ & $27(29.3 \%)$ & $47(27.5 \%)$ & $8(42.1 \%)$ & $38(22.0 \%)$ & 0.322 \\
\hline Previous CHF & $38(24.8 \%)$ & $32(34.8 \%)$ & $30(17.5 \%)$ & $4(21.1 \%)$ & $41(23.7 \%)$ & 0.041 \\
\hline Previous CHD & $30(19.6 \%)$ & $29(31.5 \%)$ & $32(18.7 \%)$ & $5(26.3 \%)$ & $31(17.9 \%)$ & 0.084 \\
\hline Previous AF & $10(6.5 \%)$ & $32(34.8 \%)$ & $9(5.3 \%)$ & $0(0.0 \%)$ & $17(9.8 \%)$ & $<0.001$ \\
\hline Previous use antiplatelets & $53(34.6 \%)$ & $48(52.2 \%)$ & $45(26.3 \%)$ & $5(26.3 \%)$ & $60(34.7 \%)$ & 0.001 \\
\hline Previous use anticoagulants & $3(2.0 \%)$ & $15(16.3 \%)$ & $3(1.8 \%)$ & $0(0.0 \%)$ & $6(3.5 \%)$ & 0.863 \\
\hline
\end{tabular}

LLA: large-artery atherosclerosis; CE: cardioembolic; SVO: small vessel occlusion; BMI: body mass index; TIA: transitory ischemic attack; CHF: cardiac heart failure; CHD: coronary heart disease; AF: atrial fibrillation; *available for only 599 cases (LAA:151; CE:91; SVO:171; OTH:19; UND:116).

\section{DISCUSSION}

In Joinville, in the years 2005 and 2006, the higher incidence rates observed in the present study were for UND, SVO and LAA subtypes. The incidence of LAA was almost two-fold higher in men than in women. One year after FEIS, the higher mortality rate was observed for UND and CE subtypes. The OTH subtype presented lower mortality rates than for the other subtypes.

In Iquique, Chile, the world standardized incidence for atherothrombotic IS was $2.8 / 100,000$. However, only $25 \%$ of those patients underwent carotid duplex ultrasound 9 . In our sample, all patients were assessed using confirmatory methods, and those patients who had an incomplete investigation were included in the UND subtype. The rates for the SVO, CE and UND subtypes were similar in both studies?

Despite performance of biochemical, electrocardiographic, extracranial and intracranial Doppler ultrasound, transthoracic echocardiography and at least one brain CT in all the patients in the current study, a significant number of strokes of UND subtype was observed. This was previously reported in epidemiological studies based on the same pathophysiological classification ${ }^{2,3,4,10}$. Recent studies have chosen different criteria for stroke subtype definition ${ }^{5,22}$. These new criteria, combined with advanced diagnostic techniques, could help reducing the cryptogenic stroke observed in UND subtype $^{23}$. In addition, not all of the patients in the present study were submitted to Holter monitoring and/or transesophageal echocardiography. This may partially explain the relative low incidence of CE subtype Unfortunately, we do not have the exact number of patients submitted to these methods.

The epidemiology of IS subtypes in White patients from South America was previously analyzed in two hospital-based studies $^{24,25}$. In Buenos Aires, Argentina, $42 \%$ of all IS subtypes were $\mathrm{SVO}^{24}$. In Porto Alegre city, also in southern Brazil, 32\% were $\mathrm{LAA}^{25}$. These finding could be related to dietary conditions, the poor control of risk factors, socioeconomic conditions, age, sex and race ${ }^{24,25}$. However, the study design was not suitable for these analyses because non-hospitalized patients had differences in the etiological subtypes and risk factors compared to hospitalized patients ${ }^{26}$.

The incidence of LAA in Joinville was similar to that in previous studies of mostly White populations. In two recent population-based studies focused on a predominantly White population, a high incidence of the LAA subtype was reported, which might be related to the stroke pathophysiology classification system used, distinct of the classic TOAST classification $^{5.8}$. In our study, the incidence observed could be explained by the prevalence of risk factors and possibly genetic susceptibility, because most of the Brazilian population has some amount of African genomic ancestry, and it is recognized that ethnicity is an important contributor to atherosclerotic risk factors $36,7,27,28$.

In a recent case-control study, hypertension, current smoking, abdominal obesity, diet and physical activity accounted for more than $80 \%$ of the global risk of stroke ${ }^{29}$. The hypertension treatment measures taken previous to stroke in the current study $(67 \%)$ were similar to those in a recent study $(77 \%)^{4}$. However, in the Adelaide Study, only $2.5 \%$ of 
Table 3. One-year mortality rates by age and sex (per 100,000 per year) of ischemic stroke subtypes in Joinville, Brazil, 2005 -2006.

\begin{tabular}{|c|c|c|c|c|c|c|c|c|c|c|}
\hline \multirow{2}{*}{ Age (years) } & \multicolumn{2}{|r|}{ LAA } & \multicolumn{2}{|r|}{ CE } & \multicolumn{2}{|r|}{ SVO } & \multicolumn{2}{|r|}{ Other } & \multicolumn{2}{|c|}{ Undetermined } \\
\hline & $\mathrm{n}$ & Rate(95\%Cl) & $\mathrm{n}$ & Rate(95\%Cl) & $\mathrm{n}$ & Rate(95\%Cl) & $n$ & Rate(95\%Cl) & $n$ & Rate(95\%Cl) \\
\hline \multicolumn{11}{|l|}{ Men } \\
\hline \multicolumn{11}{|l|}{$0-14$} \\
\hline \multicolumn{11}{|l|}{$15-24$} \\
\hline \multicolumn{11}{|l|}{$25-34$} \\
\hline $35-44$ & & & & & & & & & 1 & $1(0-7)$ \\
\hline $45-54$ & 1 & $2(0.1-11)$ & & & & & & & 1 & $2(0.1-11)$ \\
\hline $55-64$ & 3 & $12(3-37)$ & & & & & 1 & $4(0.1-23)$ & 9 & $38(17-71)$ \\
\hline $65-74$ & 2 & $16(2-60)$ & 3 & $25(5-72)$ & 1 & $8(0.2-46)$ & & & 3 & $25(5-72)$ \\
\hline $75-79$ & 4 & $133(36-341)$ & 2 & $67(8-240)$ & & & & & 5 & 166(54-388) \\
\hline$\geq 80$ & 3 & $131(27-383)$ & 6 & $262(96-570)$ & 1 & $44(1-243)$ & & & 3 & $131(27-383)$ \\
\hline All Ages & 13 & $3(1-4)$ & 11 & $2(1-4)$ & 2 & $0.4(0-1)$ & 1 & $0.2(0-1)$ & 22 & $4(3-7)$ \\
\hline World* & & $6(1-13)$ & & $6(2-19)$ & & $1(0-8)$ & & $0.3(0-0)$ & & $9(3-23)$ \\
\hline Brazil† & & 4(1-10) & & $4(1-14)$ & & $0.8(0-5)$ & & $0.2(0-0)$ & & $7(2-16)$ \\
\hline \multicolumn{11}{|l|}{ Women } \\
\hline \multicolumn{11}{|l|}{$0-14$} \\
\hline \multicolumn{11}{|l|}{$15-24$} \\
\hline \multicolumn{11}{|l|}{$25-34$} \\
\hline $35-44$ & & & 1 & $1(0-7)$ & & & & & & \\
\hline $45-54$ & 1 & $2(0.1-11)$ & 1 & $2(0.1-11)$ & 1 & $2(0.1-11)$ & & & 3 & $6(1-17)$ \\
\hline $55-64$ & 3 & $12(2-34)$ & 4 & $16(4-40)$ & 2 & $8(0.9-28)$ & & & 1 & $4(0.1-22)$ \\
\hline $65-74$ & 6 & $37(14-81)$ & 4 & $25(7-64)$ & & & & & 4 & $25(7-64)$ \\
\hline $75-79$ & & & 2 & 44(5-160) & 1 & $22(0.6-123)$ & & & 4 & $88(24-226)$ \\
\hline$\geq 80$ & 5 & $110(36-257)$ & 9 & 198(91-377) & 1 & $22(0.6-123)$ & & & 13 & $287(153-490)$ \\
\hline All Ages & 15 & $3(2-5)$ & 21 & 4(3-6) & 5 & $1(0.3-2)$ & & & 25 & $5(3-7)$ \\
\hline World* & & $5(1-12)$ & & $7(2-17)$ & & $1(0.1-7)$ & & & & $8(3-14)$ \\
\hline Brazil† & & $3(1-9)$ & & $5(2-12)$ & & & & & & $6(2-10)$ \\
\hline \multicolumn{11}{|l|}{ All } \\
\hline \multicolumn{11}{|l|}{ 0-14 } \\
\hline \multicolumn{11}{|l|}{$15-24$} \\
\hline \multicolumn{11}{|l|}{$25-34$} \\
\hline $35-44$ & & & 1 & $0.7(0-4)$ & & & & & 1 & $0.7(0-4)$ \\
\hline $45-54$ & 2 & $2(0.2-7)$ & 1 & $1(0-6)$ & 1 & $1(0-6)$ & & & 4 & $4(1-10)$ \\
\hline $55-64$ & 6 & $12(4-26)$ & 4 & $8(2-21)$ & 2 & $4(0.5-15)$ & 1 & $2(0.1-11)$ & 10 & $20(10-37)$ \\
\hline $65-74$ & 8 & $28(12-56)$ & 7 & $25(10-51)$ & 1 & $3(0.1-20)$ & & & 7 & $25(10-51)$ \\
\hline $75-79$ & 4 & $53(14-136)$ & 4 & 53(14-136) & 1 & $13(0.3-74)$ & & & 9 & $120(55-227)$ \\
\hline$\geq 80$ & 8 & 117(51-231) & 15 & $220(123-362)$ & 2 & $29(3-106)$ & & & 16 & $234(134-381)$ \\
\hline All Ages & 28 & $3(2-4)$ & 32 & $3(2-5)$ & 7 & $0.7(0.3-1)$ & 1 & $0.1(0-0.6)$ & 47 & $5(3-6)$ \\
\hline World* & & $5(2-11)$ & & $6(3-13)$ & & $1(0.1-6)$ & & $0.2(0-0.9)$ & & $9(4-17)$ \\
\hline Brazil† & & $4(1-8)$ & & $4(2-9)$ & & $0.9(0.1-4)$ & & $0.1(0-0.7)$ & & $6(3-12)$ \\
\hline
\end{tabular}

*Age adjusted to the world WHO population (2000); †Brazil population 2005-2006. LLA: large-artery atherosclerosis; CE: cardioembolic; SVO: small vessel occlusion; Cl: confidence interval.

hypertension patients did not have it controlled ${ }^{4}$. In contrast, we found that $21 \%$ of previous hypertensive patients, even when regularly treated, did not have it controlled before hospital admission. In the last decade, measures were started to reduce the cardiovascular death in Brazil by controlling risk factors $^{12,30,31}$. However, a Brazilian telephone survey demonstrated that obesity and diabetes have been continuously increasing in the last five years, though fortunately smoking has been reduced by $2.1 \%$ in the same period ${ }^{32}$.

The higher mortality rates observed for UND and CE were described previously in the Mestizo sample in Chile and in other predominantly White population studies, where the authors also demonstrated that LAA had elevate mortality rates as shown in the present study ${ }^{1,2}$.

This study has some limitations. First, race-ethinicity was based on skin color classification of the IBGE, responsible for the official census of Brazi ${ }^{33}$. Most Brazilians, have a predominantly European genomic ancestry, with some proportion of African and Amerindian genomic ancestry ${ }^{27,28}$. Second, a large number of patients were included in the UND subtype because of a failure to be put in one of the other groups. Despite the extensive investigation performed, patients who had cryptogenic etiology were not distinguished from those who had two or more mechanisms in the UND group. Making this distinction 
could improve the understanding of the high incidence and mortality rates in this subtype. Still, previous studies with similar methodology did not report the percentage of complementary tests performed, and did not provide information about the numbers of cryptogenic strokes or of strokes caused by two or more in the UND subtype ${ }^{2,4}$. Therefore, we understand that these limitations do not reduce the importance of the present work, the first study in Latin America to demonstrate the real incidence and mortality rates of ischemic stroke subtypes in a predominantly White population.

Some risk factors were not analyzed in the current study, primarily abdominal circumference, diet and physical activity, all of which are clearly recognized as important risks to control $^{29}$. Another important issue is the non-differentiation between intracranial and extracranial atherosclerosis, a disease with high incidence in Black and Hispanic populations ${ }^{3}$. Furthermore, the current study does not represent the whole population of Brazil; the heterogeneity present in the country, where some regions are more than $40 \%$ Brown (Northeast, North and Central-West), could change the predominant risk factors and the frequency of the IS subtypes ${ }^{33}$. An ongoing study could help to address this variation in future studies because the sample is representative of different regions ${ }^{34}$.

In conclusion, the incidence and mortality rates of IS subtypes in Joinville, Brazil, were similar to those from other predominantly White population-based studies. These findings highlight the importance of better detection and control of atherosclerotic risk factors in the Brazilian population.

\section{References}

1. Petty GW, Brown RD Jr, Whisnant JP, Sicks JD, O"Fallon WM, Wiebers DO. Ischemic stroke subtypes: a population-based study of functional outcome, survival, and recurrence. Stroke. 2000;31(5):1062-8. http://dx.doi.org/10.1161/01.STR.31.5.1062

2. Kolominsky-Rabas PL, Weber M, Gefeller O, Neundoerfer B, Heuschmann PU. Epidemiology of ischemic stroke subtypes according to TOAST criteria: incidence, recurrence, and long-term survival in ischemic stroke subtypes: a population-based study. Stroke. 2001;32(12):2735-40. http://dx.doi.org/10.1161/hs1201.100209

3. White H, Boden-Albala B, Wang C, Elkind MS, Rundek T, Wright CB et al. Ischemic stroke subtype incidence among whites, blacks, and Hispanics: the Northern Manhattan Study. Circulation. 2005;111(10):1327-31. http://dx.doi.org/10.1161/01.CIR.0000157736.19739.D0

4. Leyden JM, Kleinig TJ, Newbury J, Castle S, Cranefield J, Anderson CS et al. Adelaide stroke incidence study: declining stroke rates but many preventable cardioembolic strokes. Stroke. 2013;44(5):1226-31. http://dx.doi.org/10.1161/STROKEAHA.113.675140

5. Palm F, Urbanek C, Wolf J, Buggle F, Kleemann T, Hennerici $M G$ et al. Etiology, risk factors and sex differences in ischemic stroke in the Ludwigshafen Stroke Study, a population-based stroke registry. Cerebrovasc Dis. 2012;33(1):69-75. http://dx.doi.org/10.1159/000333417

6. Schneider AT, Kissela B, Woo D, Kleindorfer D, Alwell K, Miller R et al. Ischemic stroke subtypes: a population-based study of incidence rates among blacks and whites. Stroke. 2004;35(7):1552-6. http://dx.doi.org/10.1161/01.STR.0000129335.28301.f5

7. Hajat C, Heuschmann PU, Coshall C, Padayachee S, Chambers $J$, Rudd AG et al. Incidence of aetiological subtypes of stroke in a multi-ethnic population based study: the South London Stroke Register.J Neurol Neurosurg Psychiatry. 2011;82(5):527-33. http://dx.doi.org/10.1136/jnnp.2010.222919

8. Bejot Y, Caillier M, Ben Salem D, Couvreur G, Rouaud O, Osseby GV et al. Ischaemic stroke subtypes and associated risk factors: a French population based study. J Neurol Neurosurg Psychiatry. 2008;79(12):1344-8. http://dx.doi.org/10.1136/jnnp.2008.150318

9. Lavados PM, Sacks C, Prina L, Escobar A, Tossi C, Araya F et al. Incidence, case-fatality rate, and prognosis of ischaemic stroke subtypes in a predominantly Hispanic-Mestizo population in Iquique, Chile (PISCIS project): a community-based incidence study. Lancet Neurol. 2007;6(2):140-8. http://dx.doi.org/10.1016/S1474-4422(06)70684-6

10. Cabral NL, Gonçalves AR, Longo AL, Moro CH, Costa G, Amaral $\mathrm{CH}$ et al. Incidence of stroke subtypes, prognosis and prevalence of risk factors in Joinville, Brazil: a 2 year community based study.J Neurol Neurosurg Psychiatry. 2009;80(7):755-61. http://dx.doi.org/10.1136/jnnp.2009.172098

11. Minelli C, Fen LF, Minelli DP. Stroke incidence, prognosis, 30-day, and 1-year case fatality rates in Matão, Brazil: a population-based prospective study. Stroke. 2007;38(11):2906-11. http://dx.doi.org/10.1161/STROKEAHA.107.484139

12. Martins SC, Pontes-Neto OM, Alves CV, Freitas GR, Oliveira Filho J, Tosta ED et al. Past, present, and future of stroke in middle-income countries: the Brazilian experience. Int J Stroke. 2013; 8(Suppl A100):100-6. http://dx.doi.org/10.1111/ijs.12062

13. Lotufo PA, Benseñor IM. Stroke mortality in Brazil: one example of delayed epidemiological cardiovascular transition. Int J Stroke, 2009;4(1):40-1. http://dx.doi.org/10.1111/j.1747-4949.2009.00240.x

14. Ministério da Saúde (BR). [Estimativas preliminares para os anos intercensitários dos totais populacionais, estratificadas por idade e sexo pelo MS/SGEP/Datasus]. Brasília, DF: Datasus; 2013 [cited 2013 May 20]. Available from: http://tabnet.datasus.gov.br/cgi/ deftohtm.exe?ibge/cnv/popsc.def

15. Instituto Brasileiro de Geografia e Estatística - IBGE. Censo 2010. Rio de Janeiro: Instituto Brasileiro de Geografia e Estatística; 2013 [cited 2013 May 20]. Available from: www.censo2010.ibge.gov.br/apps/mapa/

16. Aho K, Harmsen P, Hatano S, Marquardsen J, Smirnov VE, Strasser T. Cerebrovascular disease in the community: results of a WHO collaborative study. Bull World Health Organ. 1980;58(1):113-30.

17. Sociedade Brasileira de Doenças Cerebrovasculares. [Brazilian guideline for the management of acute stroke]. Arq Neuropsiquiatr. 2001;59(4):972-80. Portuguese. http://dx.doi.org/10.1590/S0004-282X2001000600026

18. Bamford J, Sandercock P, Dennis M, Burn J, Warlow C. Classification and natural history of clinically identifiable subtypes of cerebral infarction. Lancet. 1991;337(8756):1521-6. http://dx.doi.org/10.1016/0140-6736(91)93206-0

19. Adams HP Jr, Bendixen BH, Kappelle LJ, Biller J, Love BB, Gordon $\mathrm{DL}$ et al. Classification of subtype of acute ischemic stroke. Definitions for use in a multicenter clinical trial. TOAST. Trial of Org 10172 in Acute Stroke Treatment. Stroke. 1993;24(1):35-41. http://dx.doi.org/10.1161/01.STR.24.1.35

20. Ministério da Saúde (BR). [Estimativas preliminares para os anos intercensitários dos totais populacionais, estratificadas por idade e sexo pelo MS/SGEP/Datasus]. Brasília, DF: Datasus; 2013 [cited 2013 May 20]. Available from: http://tabnet.datasus.gov.br/cgi/ tabcgi.exe?ibge/cnv/popuf.def 
21. Ahmad OB, Boschi-Pinto C, Lopez AD, Murray CJL, Lozano R, Inone M. Age standardisation of rates: a new WHO world standard. Geneve: World Health Organization; 2001 [cited 2013 May 20]. (GPE Discussion Paper Series, vol 31). Available from: www.who.int/ healthinfo/paper31.pdf

22. Marnane M, Duggan CA, Sheehan OC, Merwick A, Hannon N, Curtin $D$ et al. Stroke subtype classification to mechanism-specific and undetermined categorie by TOAST, A-S-C-O, and causative classification system: direct comparison in the North Dublin populaiton stroke study. Stroke. 2010;41(8):1579-86. http://dx.doi.org/10.1161/STROKEAHA.109.575373

23. Bang OY, Ovbiagele B, Kim JS. Evaluation of cryptogenic stroke with advanced diagnostic techniques. Stroke. 2014;45(4):1186-94. http://dx.doi.org/10.1161/STROKEAHA.113.003720

24. Saposnik G, Caplan LR, Gonzalez LA, Baird A, Dasche J, Luraschi A et al. Differences in stroke subtypes among natives and caucasians in Boston and Buenos Aires. Stroke. 2000;31(10):23859. http://dx.doi.org/10.1161/01.STR.31.10.2385

25. Porcello Marrone LC, Diogo LP, Oliveira FM, Trentin S, Scalco RS, Almeida AG et al. Risk factors among stroke subtypes in Brazil. J Stroke Cerebrovasc Dis. 2013;22(1):32-5. http://dx.doi.org/10.1016/j.jstrokecerebrovasdis.2011.05.022

26. Schulz UG, Rothwell PM. Differences in vascular risk factors between etiological subtypes of ischemic stroke: importance of population-based studies. Stroke. 2003;34(8):2050-9. http://dx.doi.org/10.1161/01.STR.0000079818.08343.8C

27. Cardena MM, Ribeiro-Dos-Santos A, Santos S, Mansur AJ, Pereira AC, Fridman C. Assessment of the relationship between self-declared ethnicity, mitochondrial haplogroups and genomic ancestry in brazilian individuals. PLoS One. 2013;8(4):e62005. http://dx.doi.org/10.1371/journal.pone.0062005
28. Pena SD, Di Pietro G, Fuchshuber-Moraes M, Genro JP, Hutz $\mathrm{MH}$, Kehdy FS et al. The genomic ancestry of individuals from different geographical regions of Brazil is more uniform than expected. PLoS One. 2011;6(2):e17063. http://dx.doi.org/10.1371/journal.pone.0017063

29. O'Donnell MJ, Xavier D, Liu L, Zhang H, Chin SL, Rao-Melacini Pet al. Risk factors for ischaemic and intracerebral haemorrhagic stroke in 22 countries (the INTERSTROKE study): a case-control study. Lancet. 2010;376(9735):112-23. http://dx.doi.org/10.1016/S0140-6736(10)60834-3

30. Schmidt MI, Duncan BB, Silva GA, Menezes AM, Monteiro CA, Barreto SM et al. Chronic non-communicable diseases in Brazil: burden and current challenges. Lancet. 2011;377(9781):1949-61. http://dx.doi.org/10.1016/S0140-6736(10)60834-3

31. Ministério da Saúde (BR). Protocolos clínicos e diretrizes terapêuticas. Brasília, DF: Ministério da Saúde; 2012 [cited 2013 May 20]. Available from: http://portal.saude.gov.br/portal/arquivos/pdf/ pcdt_trombolise_avc_isq_agudo.pdf

32. Ministério da Saúde (BR), Secretaria de Vigilância em Saúde. Vigitel Brasil 2011: vigilância de fatores de risco e proteção para doenças crônicas por inquérito telefônico. Brasília, DF: Ministério da Saúde; 2012 [cited 2013 May 20]. (Série G. Estatística e Informação em Saúde). Available from: http://bvsms.saude.gov.br/bvs/publicacoes/ vigitel_brasil_2011_final.pdf

33. Ministério do Planejamento, Orçamento e Gestão (BR); Instituto Brasileiro de Geografia e Estatística. Características étnico-raciais da população: um estudo das categorias de classificação de cor ou raça: 2008. Rio de Janeiro: Instituto Brasileiro de Geografia e Estatística; 2011.

34. Aquino EM, Barreto SM, Bensenor IM, Carvalho MS, Chor D, Duncan BB et al. Brazilian Longitudinal Study of Adult Health (ELSA-Brasil): objectives and design. Am J Epidemiol. 2012;175(4):315-24. http://dx.doi.org/10.1093/aje/kwr294 